\title{
The bactericidal activity of DR-3355, an optically active isomer of ofloxacin
}

\author{
C. S. LEWIN and S. G. B. AMYES
}

Department of Bacteriology, The Medical School, University of Edinburgh, Teviot Place, Edinburgh EH89AG

\begin{abstract}
Summary. The bactericidal activity of compound DR-3355, an optically active isomer of ofloxacin, was measured against Escherichia coli, Staphylococcus aureus and $S$. epidermidis, in nutrient broth and in phosphate-buffered saline. DR-3355 was found to be approximately twice as active as ofloxacin in terms of the concentration at which maximum bacterial kill was achieved. Hence it appears that DR-3355 is twice as active as ofloxacin not only in terms of its ability to inhibit bacterial multiplication but also in its ability to kill bacteria. DR-3355 was found to be active against nondividing bacteria and did not require either active RNA or protein biosynthesis in order to kill bacteria.
\end{abstract}

\section{Introduction}

Ofloxacin (fig. 1) is a 4-quinolone antibacterial agent which is characterised chemically by a tricyclic structure with a methyl group at the C-3 position in the oxazine ring. Two optically active isomers of this compound, $\mathbf{S}(-)$ ofloxacin and $\mathbf{R}$ $(+)$ ofloxacin, can exist. DR-3355 is the S-isomer of ofloxacin and has been shown to be twice as active as ofloxacin in terms of its minimum inhibitory concentration (MIC) against a wide range of clinical isolates. ${ }^{1}$ However, MICs measure only the inhibition of bacterial multiplication by the 4-quinolones and not the death of bacteria caused by these drugs. ${ }^{2}$ Therefore, it was decided to determine both the bactericidal activity and the mechanisms of action of DR-3355 against Escherichia coli, Staphylococcus aureus and S. epidermidis.

Three independent mechanisms of action, A, B and $\mathrm{C}$, have been found to be responsible for the bactericidal activity of the 4-quinolones against these species. Mechanism A was the first bactericidal mechanism to be identified in the 4-quinolones. It is exhibited by all 4-quinolones and is the sole bactericidal mechanism of nalidixic and oxolinic acids. ${ }^{2,3}$ The prerequisites for the bactericidal activity of mechanism $A$ are protein and RNA biosynthesis, as well as the bacteria being capable of division. Hence chloramphenicol, an inhibitor of protein synthesis, or rifampicin, an inhibitor of RNA synthesis, completely abolish the bactericidal activity of nalidixic acid against $E$. coli ${ }^{3,4}$ On the

Received 13 March 1989; accepted 4 May 1989<smiles>[R]Oc1c(N2CCN(C)CC2)c(F)cc2c(=O)c(C(=O)O)cn([R])c12</smiles>

$$
\begin{aligned}
& \text { Ofloxacin } \mathrm{R}=-\mathrm{CH}_{3} \\
& \text { DR }-3355 \mathrm{R}=4 \mathrm{CH}_{3}
\end{aligned}
$$

Fig. 1. Chemical structures of ofloxacin and DR-3355.

other hand, a bacteriostatic concentration of either chloramphenicol or rifampicin merely reduces, but does not abolish, the bactericidal activity of ofloxacin or ciprofloxacin against $E$. coli KL16 in nutrient broth. ${ }^{3,5}$ Thus it was proposed that these two 4-quinolones possessed a second bactericidal mechanism that did not require protein or RNA synthesis for its activity. Mechanism B was later shown to be active against non-dividing bacteria. ${ }^{6,7}$ Mechanism $\mathrm{C}$, the third bactericidal mechanism exhibited by some 4-quinolones, is also active against non-dividing bacteria but, unlike mechanism B, protein and RNA synthesis are required for its bactericidal activity. ${ }^{8}$ Mechanism $\mathrm{C}$ is exhibited by enoxacin (C. S. Lewin, unpublished results) and norfloxacin. ${ }^{8}$ 


\section{Materials and methods}

\section{Bacterial strains}

The bacterial strains used were $E$. coli $\mathrm{KL} 16,{ }^{3} S$. aureus $\mathrm{E} \mathrm{T}^{9}$ and $S$. epidermidis SK $360 .^{10}$

\section{Antibacterial agents}

DR-3355 (Daiichi Seiyaku Co. Ltd.) and chloramphenicol (Parke Davis) were dissolved in sterile distilled water to provide stock solutions from which dilutions were made.

\section{Dose response studies}

Sterile double-strength nutrient broth (Nutrient Broth No. 2, Oxoid) was dispensed in $2.5-\mathrm{ml}$ volumes into sterile $1-\mathrm{oz}$ bottles. Aqueous drug solutions and sterile distilled water totalling $2.4 \mathrm{ml}$ were added to the $1-\mathrm{oz}$ bottles to provide the range of drug concentrations tested. The concentration of drug used in each bactericidal test was based on the following progression $(\mathrm{mg} / \mathrm{L}): 1,5,3,5$, 9 and 15 . The bottles were placed in a water bath at $37^{\circ} \mathrm{C}$ and pre-warmed for at least $15 \mathrm{~min}$. Then $0.1 \mathrm{ml}$ of an overnight nutrient-broth culture containing approximately $5 \times 10^{8} \mathrm{cfu} / \mathrm{ml}$ was added to complete each reaction mixture, providing an initial viable count of approximately $10^{7} \mathrm{cfu} / \mathrm{ml}$. The reaction mixtures were then incubated at $37^{\circ} \mathrm{C}$. After $3 \mathrm{~h}$, survival was estimated by viable counts on nutrient agar.

\section{Measurement of rate of kill}

The rate of kill of bacteria treated with DR-3355 in nutrient broth or phosphate-buffered saline (PBS) was measured by methods described by Lewin and Smith. ${ }^{9}$

\section{Results}

When the bactericidal activity of DR-3355 in nutrient broth was examined against $E$. coli KL16, $S$. aureus E3T and S. epidermidis SK 360 the drug displayed a biphasic response (which is characteristic of the bactericidal activity of the 4-quinolones) against all three species (figs. 2, 3 and 4). The bactericidal activity of DR-3355 increased as the level of the drug was raised until a concentration known as the most bactericidal concentration (optimum bactericidal concentration) was reached. Beyond this point the drug became increasingly less bactericidal. The most bactericidal concentration of DR-3355, i.e., the concentration which caused maximum bacterial death, against $E$. coli KL16 was $0.5 \mathrm{mg} / \mathrm{L}$ (fig. 2). The most bactericidal concentration of DR-3355 against both $S$. aureus E3T and $S$. epidermidis SK 360 was $3 \mathrm{mg} / \mathrm{L}$ (figs. 3 and 4).

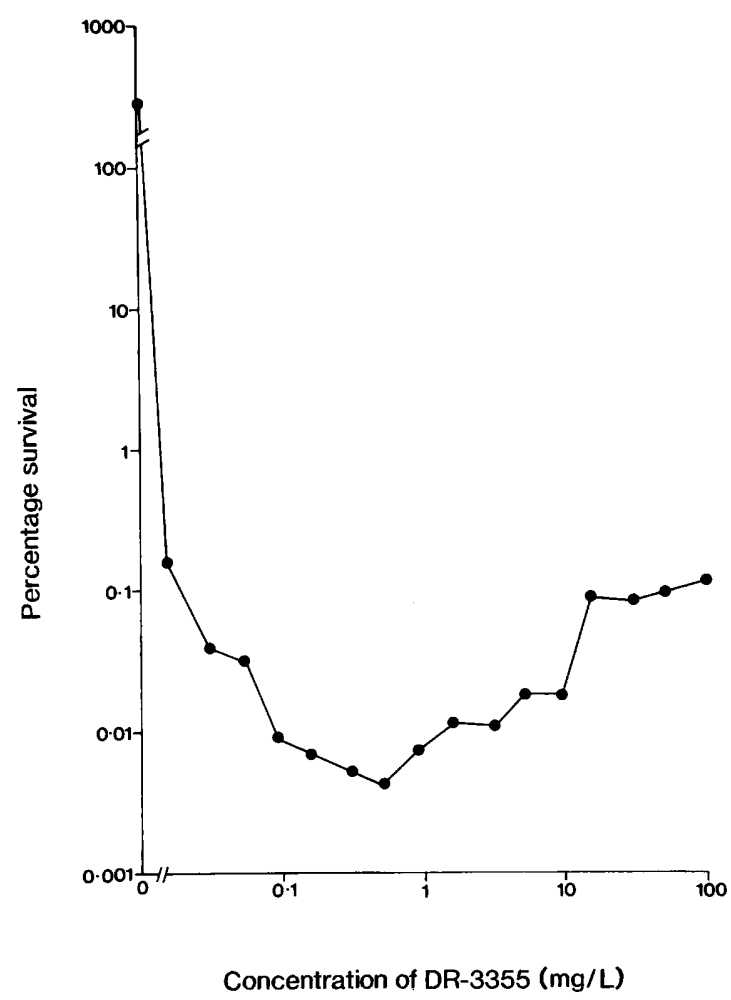

Fig. 2. Survival of E. coli KL16 after exposure to DR-3355 in nutrient broth. An overnight culture $\left(37^{\circ} \mathrm{C}\right)$ in nutrient broth was diluted 1 in 50 in fresh nutrient broth containing various concentrations of DR-3355 and incubated at $37^{\circ} \mathrm{C}$ for $3 \mathrm{~h}$.

It was then decided to investigate the bactericidal mechanisms exhibited by DR-3355 against these three species. It is assumed that DR-3355 must exhibit mechanism A because that is the bactericidal mechanism possessed by all 4-quinolones. It can be seen that DR-3355 also exhibits mechanism B against $E$. coli KL16 because the addition of chloramphenicol $20 \mathrm{mg} / \mathrm{L}$, a concentration that on its own merely inhibited bacterial multiplication but did not cause bacterial death, to DR-3355, at its most bactericidal concentration of $0.5 \mathrm{mg} / \mathrm{L}$, reduced but did not totally abolish the bactericidal activity of the drug against this species (fig. 5a). Hence DR-3355 exhibits mechanism B, which does not require bacterial protein and RNA synthesis for its activity, as well as mechanism $\mathrm{A}$ against $E$. coli KL16. Furthermore, the reduction in the amount of kill by DR-3355 when chloramphenicol was added also confirms the presence of mechanism A because protein and RNA synthesis are prerequisites for its activity. When the bactericidal activity of DR-3355 against E. coli KLl6 was investigated in PBS (in which bacteria are unable 


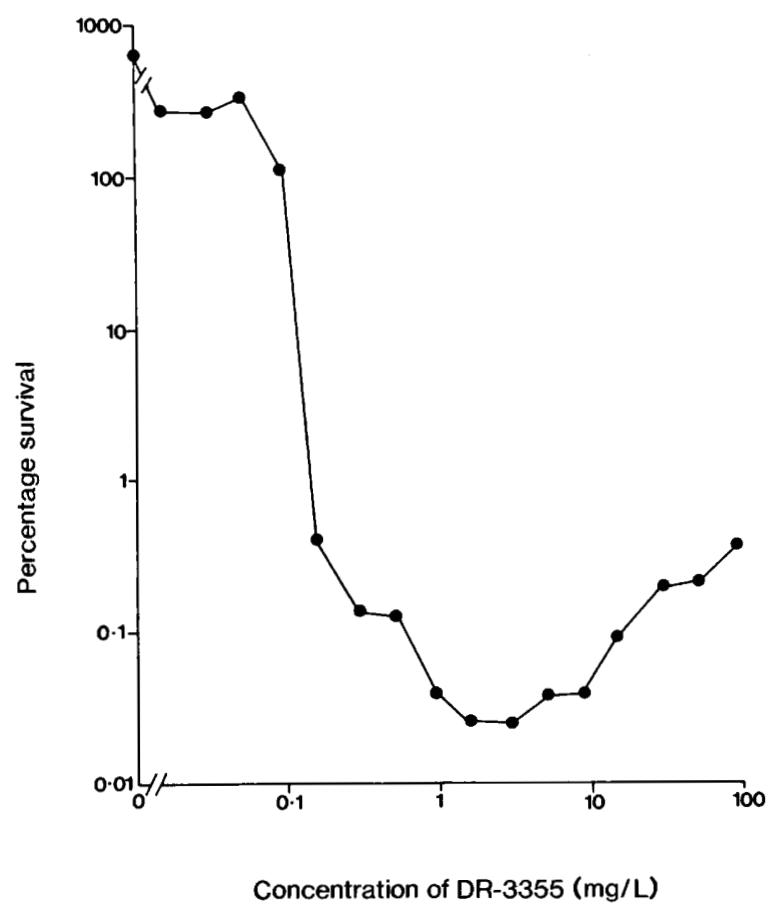

Fig. 3. Survival of $S$. aureus E3T after exposure to DR-3355 in nutrient broth. An overnight culture $\left(37^{\circ} \mathrm{C}\right)$ in nutrient broth was diluted 1 in 50 in fresh nutrient broth containing various concentrations of DR-3355 and incubated at $37^{\circ} \mathrm{C}$ for $3 \mathrm{~h}$.

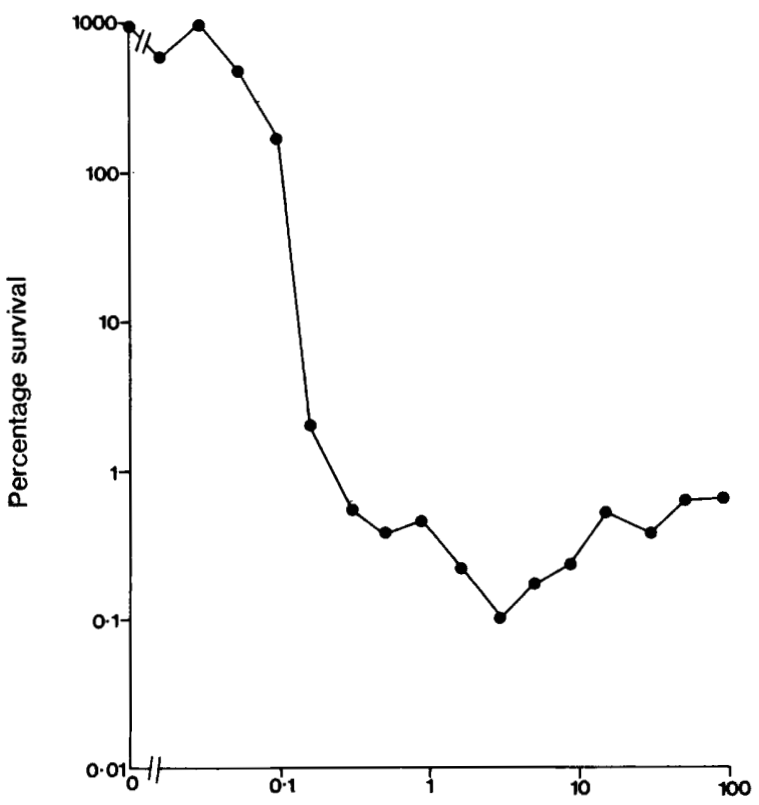

Concentration of DR-3355 ( $\mathrm{mg} / \mathrm{L})$

Fig. 4. Survival of $S$. epidermidis SK 360 after exposure to DR3355 in nutrient broth. An overnight culture $\left(37^{\circ} \mathrm{C}\right)$ in nutrient broth was diluted 1 in 50 in fresh nutrient broth containing various concentrations of DR-3355 and incubated at $37^{\circ} \mathrm{C}$ for $3 \mathrm{~h}$. a

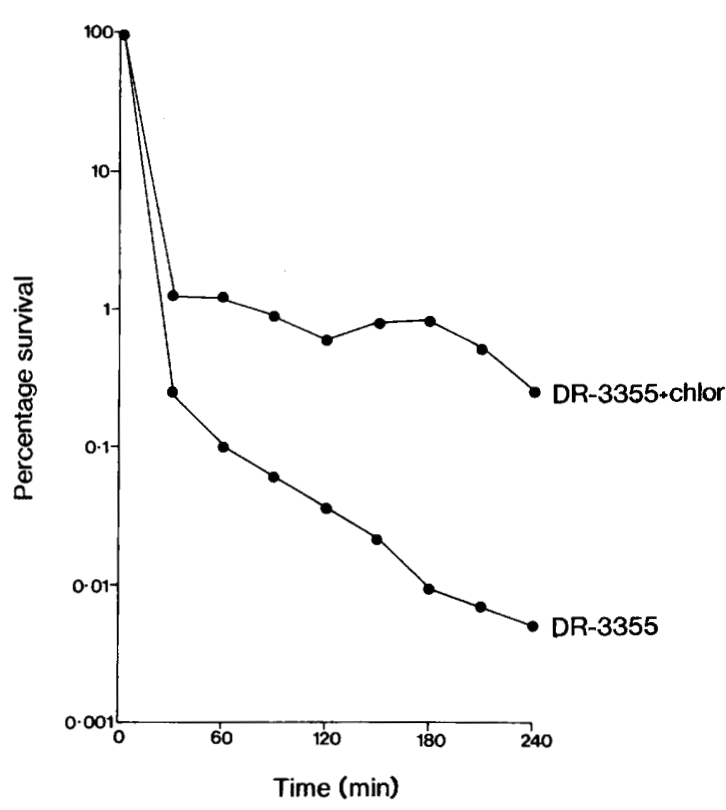

b

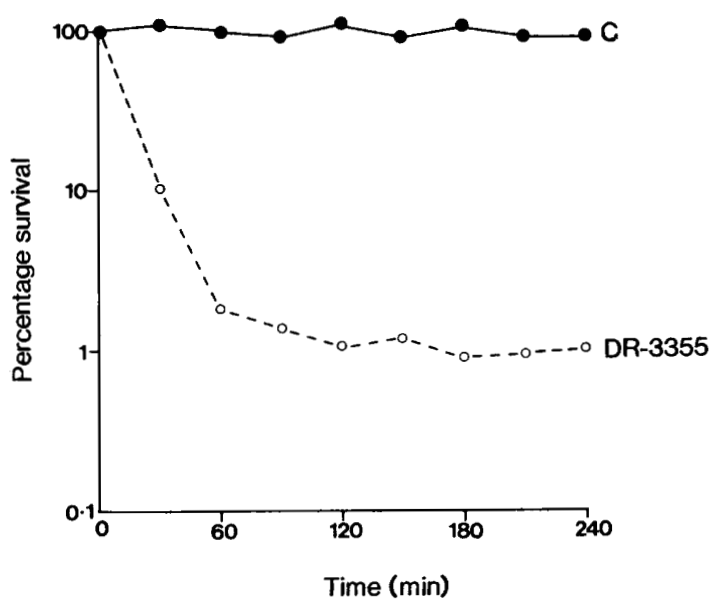

Fig. 5. Survival of E. coli KL16 in (a) nutrient broth and (b) PBS. An overnight culture $\left(37^{\circ} \mathrm{C}\right)$ in nutrient broth was diluted 1 in 50 into fresh nutrient broth or PBS containing no drug (C, PBS only), DR-3355 $0.5 \mathrm{mg} / \mathrm{L}$, or DR-3355 $0.5 \mathrm{mg} / \mathrm{L}$ + chloramphenicol $20 \mathrm{mg} / \mathrm{L}$, and incubated at $37^{\circ} \mathrm{C}$. At $30-\mathrm{min}$ intervals, percentage survival was estimated by viable counts on nutrient agar. 
to divide), the drug was bactericidal; hence, DR3355 is active against non-dividing $E$. coli (fig. 5b). This confirms that DR-3355 possesses mechanism $B$ because it is active against non-dividing bacteria.

The bactericidal mechanism possessed by DR3355 against $S$. aureus E3T and $S$. epidermidis SK 360 was also determined. The addition of chloramphenicol $10 \mathrm{mg} / \mathrm{L}$, a concentration that inhibited bacterial multiplication but did not cause bacterial death, reduced but did not completely abolish the bactericidal activity of DR-3355 against either staphylococcus in nutrient broth (figs. 6 and 7). Hence DR-3355 exhibits the chloramphenicolresistant mechanism $B$ against both staphylococci as well as against $E$. coli $\mathrm{KL} 16$. In contrast ciprofloxacin does not exhibit mechanism $B$ against staphylococci although it exerts this mechanism against $E$. coli KL16. DR-3355 was also bactericidal towards non-dividing staphylococci ( $S$. aureus and S. epidermidis SK360) suspended in PBS (figs. 6 and

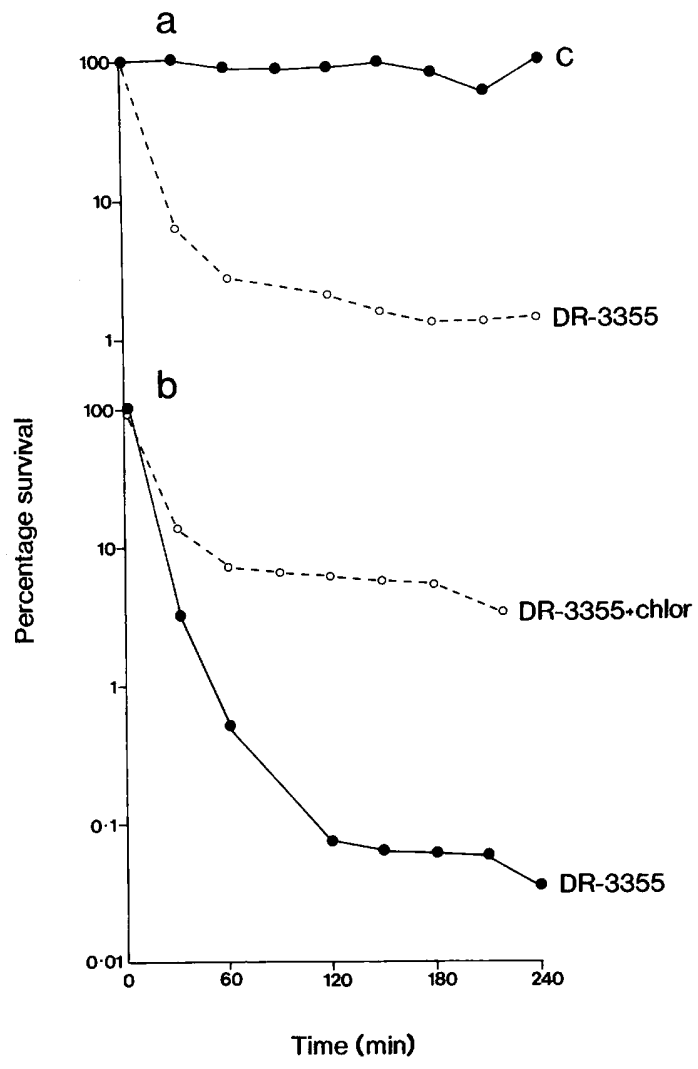

Fig. 6. Survival of $S$. aureus E3T in (a) PBS and (b) nutrient broth. An overnight culture $\left(37^{\circ} \mathrm{C}\right)$ in nutrient broth was diluted 1 in 50 in fresh nutrient broth or PBS containing no drug (C, PBS only), DR-3355 $3 \mathrm{mg} / \mathrm{L}$ or DR-3355 $3 \mathrm{mg} / \mathrm{L}$ + chloramphenicol $10 \mathrm{mg} / \mathrm{L}$ and incubated at $37^{\circ} \mathrm{C}$. At 30 -min intervals percentage survival was estimated by viable counts on nutrient agar.

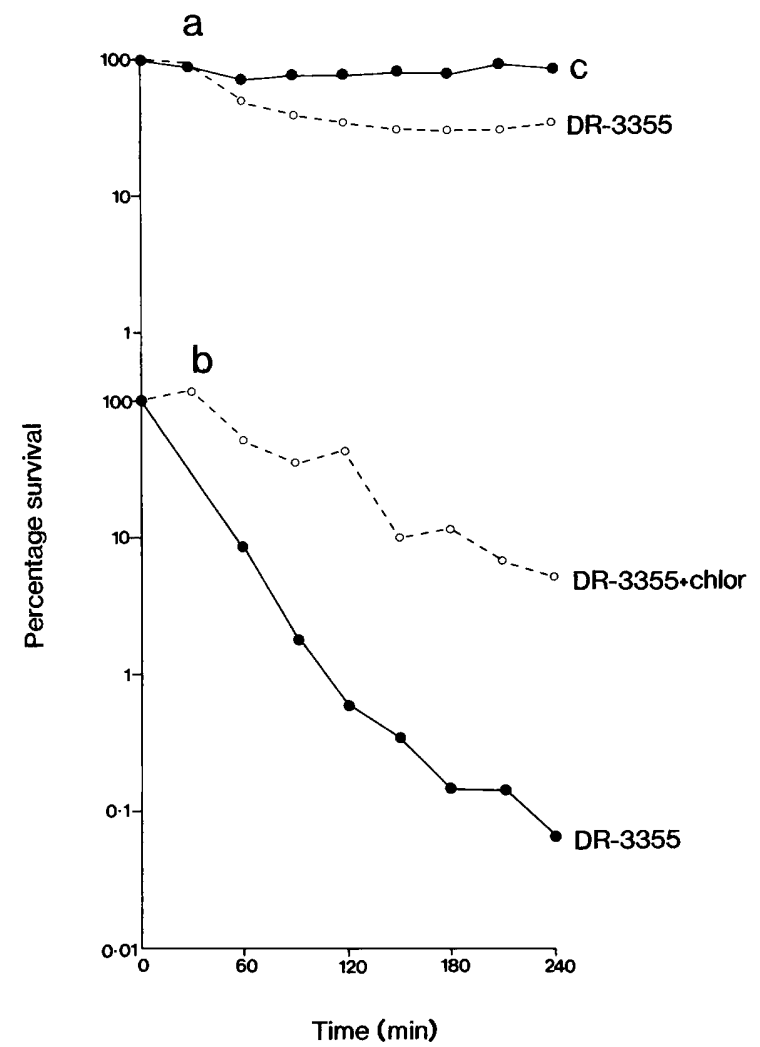

Fig. 7. Survival of $S$. epidermidis SK360 in (a) PBS and (b) nutrient broth. An overnight culture $\left(37^{\circ} \mathrm{C}\right)$ in nutrient broth was diluted 1 in 50 in fresh nutrient broth or PBS containing no drug (C, PBS only), DR-3355 $3 \mathrm{mg} / \mathrm{L}$ or DR-3355 $3 \mathrm{mg} / \mathrm{L}+$ chloramphenicol $10 \mathrm{mg} / \mathrm{L}$ and incubated at $37^{\circ} \mathrm{C}$. At $30-\mathrm{min}$ intervals percentage survival was estimated by viable counts on nutrient agar.

7) which confirms the presence of mechanism $B$. Hence DR-3355 exhibits mechanism B which is able to kill non-dividing bacteria and does not require bacterial protein or RNA synthesis for its activity against both gram-positive and gramnegative bacteria.

\section{Discussion}

When the bactericidal activity of DR-3355 was investigated against $E$. coli $\mathrm{KL} 16, S$. aureus $\mathrm{E} 3 \mathrm{~T}$ and $S$. epidermidis SK360, the agent was found to display a biphasic response characteristic of all 4quinolones that have been investigated so far, $2,3,11$ against all three species. The most bactericidal concentration (the optimum bactericidal concentration) of DR-3355 in nutrient broth against $E$. coli, $S$. aureus E3T and $S$. epidermidis SK360 appeared to be approximately half that of ofloxacin 
in all three cases. ${ }^{3,9}$ Hence DR-3355 seems to be twice as active as ofloxacin, not only in terms of the MIC, ${ }^{1}$ but also in its bactericidal activity. Only ciprofloxacin, with a most bactericidal concentration of $0 \cdot 15 \mathrm{mg} / \mathrm{L},{ }^{3}$ has greater bactericidal activity than DR-3355 against E. coli. However, the bactericidal activity of DR-3355 is as potent as ciprofloxacin against staphylococci.

The reduction of the most bactericidal concentration against $E$. coli from $0.9 \mathrm{mg} / \mathrm{L}$ for ofloxacin ${ }^{3}$ to $0.5 \mathrm{mg} / \mathrm{L}$ for DR-3355 is not particularly significant as the concentration of either drug required for optimum killing is well within their peak serum levels. This assumes that the pharmacokinetics of DR-3355 are similar to those of ofloxacin and preliminary reports suggest that this is indeed the case. ${ }^{12}$ However, the reduction in the amount of DR-3355 required to achieve optimum killing against staphylococci might be of much greater significance. The most bactericidal concentrations for ofloxacin against staphylococci are $5 \mathrm{mg} / \mathrm{L}$ or higher, ${ }^{9}$ slightly above the peak serum level of ofloxacin, ${ }^{13}$ whereas the $3 \mathrm{mg} / \mathrm{L}$ value for DR-3355 should be within its peak serum level. Therefore DR-3355 may be more effective than ofloxacin in treating staphylococcal infections.

DR-3355 was found to exhibit mechanism B

\section{REFERENCES}

1. Une T, Fujimoto T, Sato K, Osada Y. In vitro activity of DR-3355, an optically active ofloxacin. Antimicrob Agents Chemother 1988; 32: 1336-1340.

2. Smith J T, Lewin C S. Chemistry and mechanisms of action of the quinolone antibacterials. In: Andriole V T (ed) The quinolones. London, Academic Press. 1988: pp 23-82.

3. Smith J T. Awakening the slumbering potential of the 4quinolone antibacterials. Pharm J 1984; 233: 299-305.

4. Dietz W H, Cook T M, Goss W A. Mechanism of action of nalidixic acid on Escherichia coli: III conditions required for lethality. J Bacteriol 1966; 91 : 768-773.

5. Ratcliffe N T, Smith J T. Ciprofloxacin and ofloxacin exhibit a rifampicin-resistant bactericidal mechanism not detectable in other 4-quinolone antibacterial agents. $J$ Pharm Pharmacol 1984; 36 : 59.

6. Zeiler H-J, Grohe $\mathrm{K}$. The in vitro and in vivo activity of ciprofloxacin. Eur J Clin Microbiol 1984; 3: 339-343.

7. Chalkley L J, Koornhof $\mathbf{H} \mathbf{J}$. Antimicrobial activity of ciprofloxacin against Pseudomonas aeruginosa, Escherichia coli and Staphylococcus aureus determined by the killing curve method: antibiotic comparisons and synergistic interactions. Antimicrob Agents Chemother 1985; 28: 331342.

8. Ratcliffe N T, Smith J T. Norfloxacin has a novel which does not require protein or RNA synthesis for its activity and is active against non-dividing bacteria of $E$. coli and both staphylococcal species. Thus DR-3355 exerts the same two bactericidal mechanisms (A and B) that ofloxacin displays against these species. ${ }^{5,9}$ Ciprofloxacin and DR3355 appear to be equipotent against staphylococci in terms of their most bactericidal concentrations ${ }^{9}$ but DR-3355 exhibits mechanism B against staphylococci whereas ciprofloxacin does not. ${ }^{9,14}$ In this context it is interesting to note that despite inducing resolution of staphylococcal infections in most cases, ciprofloxacin does not always achieve a bacteriological cure ${ }^{15,16}$ and it is possible that eradication of bacteria may require mechanism $\mathbf{B}$. Hence DR-3355 may have the potential to eradicate staphylococcal infections which cannot be eradicated by ciprofloxacin.

In conclusion, DR-3355 seems to be more active than ofloxacin in terms of its bactericidal activity. It exhibits bactericidal mechanisms $A$ and $B$ against both gram-positive and gram-negative bacteria and hence is able to kill non-dividing bacteria.

We are very grateful to the Scottish Home and Health Department for a grant which funded this work and to $\mathrm{Dr} T$. Une of Daiichi Seiyaku for his interest. bactericidal mechanism unrelated to that of other 4quinolones. J Pharm Pharmacol 1985; 37 : 92.

9. Lewin C S, Smith J T. Bactericidal mechanisms of ofloxacin. $J$ Antimicrob Chemother 1988; 22 suppl C: 1-8.

10. Tennent J M, Young H K, Lyon B R, Amyes S G B, Skurray R A. Trimethoprim resistance determinants encoding a dihydrofolate reductase in clinical isolates of Staphylococcus aureus and coagulase-negative staphylococci. J Med Microbiol 1988; 26: 67-73.

11. Piddock L J V, Andrews J M, Diver J M, Wise R. In vitro studies of S-25930 and S-25932, two new 4-quinolones. Eur $J$ Clin Microbiol 1986; 5: 303-310.

12. Nakashima $\mathbf{M}$, Vematsu $T$, Kangmaru M, Okazaki $O$, Hashimoto S, Tachizawa H. Pharmacokinetics of DR3355 , a new quinolone, in healthy volunteers. Abstracts of the 28th Interscience Conference on Antimicrobial Agents and Chemotherapy 1988: p 951 .

13. Lockley $\mathbf{M} \mathbf{R}$, Wise $\mathbf{R}$, Dent $\mathbf{J}$. The pharmacokinetics and tissue penetration of ofloxacin. J Antimicrob Chemother $1984 ; 14: 647-652$.

14. Lewin C S, Smith J T. Ciprofloxacin does not exhibit mechanism B against Staphylococcus albus. J Pharm Pharmacol 1987; 39: 21 .

15. Righter J. Ciprofloxacin treatment of Staphylococcus Operator: $H C$ Date: $26-8-89$

16. Wood M J, Logan M N. Ciprofloxacin for soft tissue infections. J Antimicrob Chemother 1986; 18 suppl D: 159164. 